Journal of Health Promotion and Behavior (2016), 1(1): 26-31

https://doi.org/10.26911/thejhpb.2016.01.01.04

\title{
Path Analysis on Factors Affecting the Willingness to Accept Vasectomy among Men in Sanden Community Health Center, Bantul, Yogyakarta, Indonesia
}

\author{
Dechoni Rahmawati'), Bhisma Murti²), Argyo Demartoto3) \\ ${ }^{1)}$ School of Health Jenderal Ahmad Yani, Yogyakarta \\ 2)Faculty of Medicine, Universitas Sebelas Maret \\ 3)Department of Social and Political Sciences, Universitas Sebelas Maret
}

\begin{abstract}
Background: Family Planning Program is a program initiated by the government to improve the quality of life in Indonesia. One of contraception methods for men is MOP (Operation Method Man) or a vasectomy. Most of society norms regard that family planning is the area of women and men do not need to be involved is also one reason for the lack of participation of men in family planning. This study aimed to investigate of path analysis on factors affecting the willingness of husband as vasectomy acceptors.

Subjects and Method: This was observational analytic study with case control design. This was conducted in Sanden community health center, Bantul, Yogyakarta, Indonesia. A total sample of 90 respondents was selected by fixed disease sampling. The dependent variable was husband willingness. The independent variables were intention, attitude, subjective norm, and perceived behavioral control. The data were collected by questionnaire and analyzed by path analysis.

Results: There is no direct correlation between attitude and willingness of husband as an acceptor of vasectomy $(b=3.21 ; 95 \% \mathrm{CI}=1.74$ to $4.69 ; \mathrm{p}<0.001)$, an indirect correlation between subjective norms and husband's willingness as vasectomy acceptors $(b=2.08 ; 95 \% \mathrm{CI}=0.44$ to $3.72 ; \mathrm{p}=$ 0.013), perceived behavioral $(b=1.73 ; 95 \% \mathrm{CI}=0.25$ to $3.20 ; \mathrm{p}=0.021)$, a direct correlation between the perception of behavioral control and a husband's willingness as an acceptor of vasectomy $(b=1.49 ; 95 \% \mathrm{CI}=0.36$ to $3.62 ; \mathrm{p}=0.010)$ intention and willingness husband's vasectomy using (the value of coefficient $b=2.13 ; 95 \% \mathrm{CI}=1.00$ to $3.27 ; \mathrm{p}<0.001$ ).

Conclusion: There is an indirect and direct correlation of husband's willingness as an acceptor of vasectomy by Theory of Planned Behaviour.
\end{abstract}

Keywords: attitude, subjective norms, perceived behavioral, intention, willingness

Correspondence:

Dechoni Rahmawati. School of Health Jenderal Ahmad Yani, Yogyakarta.

\section{BACKGROUND}

Family Planning is a program initiated by the government to improve the quality of life in Indonesia. It is enacted in The Law of the Republic of Indonesia No. 52/2009.

The Law of the Republic of Indonesia No. 52/2009 about Demographic Growth and Family Development states that $\mathrm{KB}$ is the effort to control child birth, ideal space and age to give birth, control pregnancy, through promotion, protection, and aids in accordance with the reproductive rights to establish quality family. The Law supports $\mathrm{KB}$ program as one of the efforts to create healthy and quality family. Pregnancy control in $\mathrm{KB}$ program is conducted by sing contraceptives. There are various kinds of contraceptives, among others are Intra Uterine Device (IUD), Surgical procedure for women (tubectomy), Surgical procedure for men (vasectomy), implant, injection, pill, and condom.

Based on Indonesia Demographic and Health Survey (SDKI, 2013) which is listed 
in Data and Information Center Health Ministry of the Republic of Indonesia, in 1991 the number of KB participants is 49.7\%, in 1994 increases into 54.7\%, in 1997 is $57,4 \%, 2002$ is $60.3 \%$, in 2007 is $61.4 \%$, and in 2012 is $61.9 \%$. However the the number of male $\mathrm{KB}$ participants is still low that is 21.374 participants with percentage as much as $0.25 \%$ for vasectomy (BKKBN, 2013).

The study aimed to investigate the factors affecting husbands willingness as acceptors of vasectomy in the working area of Sanden Puskesmas. Planned Behavior Theory is a behavioral theory which is designed to predict and explain human behavior in individual certain context

Planned Behavior Theory which planned based on the assumption that human is rational being and tends to utilize obtained information systematically. People think about the implication of their action before deciding to do certain behavior. There are three main predictors which affect individual intention to do a certain behavior, namely attitude, norm, and PBC (Ajzen, 2005).

Vasectomy is a minor operative contraceptive method on male which is safe, simple, and effective, it take only short time of surgery and does not need any general anesthesia (Hartanto, 2010).

SUBJECTS AND METHOD
This was an analytic observational study
with a cross sectional design. The study was
conducted in Sanden Community Health
Center, from April to June 2016. A sample
of 90 men was selected by fixed-disease
sampling.
The dependent variable was husband
willingness as vasectomy acceptor. The
independent variables were intention, atti-
tude, subjective norm, and perceived beha-
vioral control. The study instrument was
questionnaire. The data were analyzed by
path analysis.

\section{RESULTS}

Sample characteristics are presented in Table 1. Most of the samples were between 41 to 50 years old, who were working as labors and whose income was < regional minimum wage.

In Table 2 it obtained the result that $47.8 \%$ of the study subjects had weak intention, and $52.2 \%$ had strong intention. $52.2 \%$ had positive attitude, $63.3 \%$ had high subjective norm, and 51.1\% had high perceived behavioral control.

Table 1. Sample Characteristics

\begin{tabular}{lllc}
\hline \multicolumn{1}{c}{ Characteristics } & \multicolumn{1}{c}{ Criteria } & n & \% \\
\hline Age (years) & $21-30$ & 17 & 18.9 \\
& $31-40$ & 25 & 27.8 \\
Occupation & $41-50$ & 48 & 53.3 \\
& Civil Servant/Armed Force/ Police & 13 & 14.4 \\
& Labor & 24 & 26.7 \\
& Self employed & 17 & 18.9 \\
Income & Private employee & 15 & 16.7 \\
& Farmer & 21 & 23.3 \\
& < Regional Minimum Wage & 57 & 63.3 \\
\hline
\end{tabular}


Journal of Health Promotion and Behavior (2016), 1(1): 26-31

https://doi.org/10.26911/thejhpb.2016.01.01.04

Table 2. Intention, attitude, perceived behavioral control

\begin{tabular}{llccc}
\hline \multicolumn{1}{c}{ Independent Variables } & Categories & n & \% & Total \% \\
\hline Intention & Weak & 43 & 47.8 & \multirow{2}{*}{100} \\
\multirow{2}{*}{ Attitude } & Strong & 47 & 52.2 & \\
\multirow{2}{*}{ Subjective Norm } & Negative & 43 & 47.8 & \multirow{2}{*}{100} \\
\multirow{2}{*}{ Perceived Behavioral Control } & Positive & 47 & 52.2 & \\
& Low & 33 & 36.7 & \multirow{2}{*}{100} \\
& High & 57 & 63.3 & \multirow{2}{*}{100} \\
\hline
\end{tabular}

Path Analysis was used to know the influence magnitude of a variable toward other variables, both direct and indirect influence. The influence magnitude of the exogenous variables is called path coefficient.
Meanwhile path coefficient it self did not have any units, so that it can be concluded that the bigger the path coefficient is, the bigger also the influence given from the variable.

Table 3. The Result of Path Analysis with STATA 13 Program

\begin{tabular}{|c|c|c|c|c|c|c|}
\hline \multirow{2}{*}{$\begin{array}{c}\text { Dependent } \\
\text { variable }\end{array}$} & & \multirow{2}{*}{$\begin{array}{l}\text { Independent } \\
\text { variables }\end{array}$} & \multirow{2}{*}{ b } & \multicolumn{2}{|c|}{$95 \% \mathrm{CI}$} & \multirow{2}{*}{$\mathbf{p}$} \\
\hline & & & & Upper Limit & Lower Limit & \\
\hline \multicolumn{7}{|l|}{ Direct Effect } \\
\hline \multirow[t]{2}{*}{ Willingness } & $\leftarrow$ & Intention & 2.13 & 3.27 & 1.00 & $<0.001$ \\
\hline & $\leftarrow$ & $\mathrm{PBC}$ & 1.49 & 3.62 & 0.36 & 0.010 \\
\hline \multicolumn{7}{|c|}{ Indirect Effect } \\
\hline \multirow{3}{*}{ Intention } & $\leftarrow$ & Attitude & 3.21 & 4.69 & 1.74 & $<0.001$ \\
\hline & $\leftarrow$ & Subjective Norm & 2.08 & 3.72 & 0.44 & 0.013 \\
\hline & $\leftarrow$ & $\begin{array}{l}\text { Perceived } \\
\text { Behavioral Control }\end{array}$ & 1.73 & 3.20 & 0.25 & 0.021 \\
\hline
\end{tabular}

Table 3 shows the result of calculation using SPSS STATA 13 program software. It obtained the magnitude of path coefficient of husbands' attitude on vasectomy toward intention in using vasectomy is 3.21 , with lower limit is 1.74 and upper limit is 4.69 . The result is significant, shown by the value of $\mathrm{p}<0.001$. Subjective Norm on Vasectomy toward intention in using vasectomy is 2.08, lower limit is 0.44 and upper limit is 3.72. The result is significant, shown by the value of $\mathrm{p}=0.013$. Perceived control on vasectomy toward the intention in using vasectomy is 1.73 , with lower limit is 0.25 and upper limit is 3.0. The result is significant, shown by the value of $\mathrm{p}=0.021$. Intention in using vasectomy toward husbands' wiliness as the acceptor is 2.13, with lower limit is 1.04 and upper limit is
3.27. The result is significant, shown by the value of $\mathrm{p}<0.001$. Perceived behavioral control on vasectomy toward husband willingness as the acceptor is 1.49 , with lower limit is 0.36 and upper limit is 2.62 . The result is significant, shown by the value of $\mathrm{p}=0.010$.

The effect of husband attitude toward husband willingness as acceptor of vasectomy through the intention in using vasectomy. Husbands' attitude on vasectomy is proven to be significantly affecting toward husbands' willingness as vasectomy acceptor through the intention in using vasectomy. The result is significant, shown by the value of $\mathrm{p}<0.001$.

The effect of subjective norm toward husbands' willingness as acceptor of vasectomy through the intention in using vasectomy. Subjective norm on vasectomy is 
proven to be significantly affecting toward husbands' willingness as vasectomy acceptor through the intention in using vasectomy. The result is significant, shown by the value of $\mathrm{p}=0.013$.

The effect of perceived behavioral control toward husbands' willingness as acceptor of vasectomy both directly and indirectly through the intention in using vasectomy. Perceived behavioral control on vasectomy is proven to be significantly affecting toward husbands' willingness as vasectomy acceptor both directly and indirectly through the intention in using vasectomy. The result is significant, shown by the value of $\mathrm{p}=0.021$.

The effect of intention in using vasectomy toward husbands' willingness as acceptor of vasectomy. Intention in using vasectomy is proven to be significantly affecting toward husbands' willingness as vasectomy acceptor. The result is signifycant, shown by the value of $\mathrm{p}<0.001$.

The conclusion of the study was, there was both direct and indirect association of factors affecting husbands as vasectomy acceptors. There was a direct and positive association between attitude and husband willingness as vasectomy acceptors $(b=$ 3.21, $\mathrm{p}<0.001$ ). There was an indirect association between subjective norm and husband willingness as vasectomy acceptor $(b=$ 2.08, $\mathrm{p}=$ 0.013). There was an indirect association between perceived behavior control with husband willingness as vasectomy acceptor $(b=1.73 ; p=0.021)$. There was an indirect association between perceived behavior control with husband willingness as vasectomy acceptor $(b=1.49$; $\mathrm{p}=$ 0.010). There was an indirect between intention and husband willingness in using vasectomy $(b=2.13 ; p<0.001)$.

The implication in the study was the result of the analysis showed that Theory of Plannned Behavior used in the study was in accordance with hypothesis made by the researcher. The result of the study is expected to be able to improve knowledge for the society and related institutions about vasectomy contraception so that society's understanding on vasectomy is improved, and husbands' willingness as acceptor is also improved.

Suggestion for the next researcher is to study the vasectomy topic but with different variables, theory as well as methodology.

\section{REFERENCE}

Addah AO (2014). To determine the knowledge and attitudes on modern contraceptive use amongst antenatal attendees at the Niger Delta University Teaching Hospital, Okolobiri, SouthSouth, Nigeria. IOSR Journal of Dental and Medical Sciences (IOSRJDMS). 13 (4): 01-07.

Agarwal K (2011). Family Planning and Reproductive Health. Paper Council on Foreign Relations: 1-14.

Arum DSN, Sujiyati (2009). Panduan Lengkap Pelayanan KB Terkini. Yogyakarta: Nuha Medika.

Badrujaman A (2008). Sosiologi Untuk Mahasiswa Keperawatan. Jakarta: Trans Info Media.

BKKBN (2011). Kajian implementasi kebijakan penggunaan kontrasepsi IUD. Pusat Penelitian dan Pengembangan KB-KS, Badan Kependudukan dan Keluarga Berencana Nasional.

BKKBN (2007). Badan Pusat Statistik Kementerian Kesehatan, Survei Demografi dan Kesehatan Indonesia.

BKKBN 2011). Sterilisasi kurang mendongkrak penurunan fertilitas. Pusat Penelitian dan Pengembangan KB-KS, Badan Kependudukan dan Keluarga Berencana Nasional. 
Journal of Health Promotion and Behavior (2016), 1(1): 26-31

https://doi.org/10.26911/thejhpb.2016.01.01.04

Budisantoso (2009). Partisipasi Pria dalam Keluarga Berencana di Kecamatan Jetis Kabupaten Bantul. Jurnal Promosi Kesehatan Indonesia: 4 (2).

Bunce A (2007). Factors affecting vasectomy acceptability in Tanzania. International Family Planning Perspectives. 33(1).

Christina, Sonachi, Chinomso (2014), Knowledge and attitude of men abour vasectomy as a method of family planning among married man woking in Babcock University, Ogun State, Nigeria. International Journal of Nursing and Midwifery. 7(3): 30-35

Conner M (2002). Health Behaviors. Journal University of Leeds UK.

Creswell JW (2008). Educational research: Planning, conducting, and evaluating qualitative and qualitative research (3rd ed.). (New Jersey: Pearson Merill. Prentice Hall).

Fitri M, Wantouw B, Tendean L (2013). Pengaruh Vasektomi terhadap Fungsi Seksualitas Pria. Jurnal e-Biomedik (eBM): 1 (1).

Ghozali I (2011). Model Persamaan Struktural dan Aplikasi dengan Program Amos 21. Semarang: Badan Penerbit Universitas Diponegoro.

Hanum M (2009). Sosiologi dan Antropologi Kesehatan. Yogyakarta: Nuha Medika.

Hartanto H (2010). Keluarga Berencana and Kontrasepsi, Pustaka Sinar Harapan, Jakarta.

Heejung SK, David KS, Shelley ET (2008). Culture and Sociap Support. American Psychologist.

Hidayati R (2009). Asuhan Keperawatan pada Kehamilan Fisiologis dan Patologis. Jakarta: Salemba Medika.

Indonesia Demographic and Health Survey (IDHS) (2013). Statistics Indonesia National Population and Family
Planning Board Ministry of Health. MEASURE DHS: ICF International

Isnawati D, Suhariadi F (2013). Hubungan antara dukungan sosial dengan penyesuaian diri masa persiapan pensiun pada karyawan PT Pupuk Kaltim. Jurnal Psikologi Industri dan Organisasi 2 (1): 1-6.

Jones RK (2011). Beyond birth control: The overlooked benefits of oral contraceptive pills. New York: Guttmacher Institute.

Kavanaugh ML, Anderson RM (2013). Contraception and beyond: The health benefits of services provided at family planning centers. New York: Guttmacher Institute.

Mahat K, Pacheun O, Taechaboonsermsak $P$ (2010). Intention to accept vasectomy among married men in Kathmandu, Nepal. Asia Journal of Public Health, 1(1)

Murti B (2003). Prinsip dan metode riset epidemiologi. Edisi Kedua, Jilid Pertama. Yogyakarta: Gajah Mada University Press.

Murti B (2013). Desain dan ukuran sampel untuk penelitian kuantitatif dan kualitatif di bidang kesehatan. Cetakan ketiga. Yogyakarta: Gajah Mada University Press.

Nugroho T, Utama BI (2014). Masalah kesehatan reproduksi wanita. Yogyakarta: Nuha Medika.

Pinem S (2009). Kesehatan reproduksi dan kontrasepsi. Jakarta: Trans Info Media.

Prawirohardjo S (2009). Ilmu Kebidanan. Jakarta: YBP-SP.

Rayala BZ, Viera AJ (2013). Common Questions About Vasectomy. American Family Physician 88 (11).

Samandari G, Speizer IS, O'Connell K (2010). The role of social support and parity on contraceptive use in Cam- 
bodia. International Perspectives on Sexual and Reproductive Health, 26(3).

Sarafino EP (2006). Health psychology, biopsychological interaction. New York: John Wiley \& Sons.

Sarason GI, Sarason RB (2009). Social support: Mapping the construct. Journal Vo. 26 Number 1.

Skinner BF (1938). The Behavior of Organisms: An Experimental Analysis. Cambridge, Massachusetts: B.F. Skinner Foundation.

Stright, Barbara R (2004). Keperawatan Ibu Bayi Baru Lahir. Jakarta: EGC.

Suratun (2008). Pelayanan Keluarga Berencana dan Kontrasepsi. Jakarta: Trans Infomedia.
Tukiran (2010). Keluarga Berencana dan Kesehatan Reproduksi. Yogyakarta: Nuha Medika.

Undang-Undang Republik Indonesia Nomor 52 Tahun 2009 Tentang Perkembangan Kependudukan dan Pembangunan Keluarga.

Winardi (2007). Manajemen Perilaku Organisasi. Cetakan kedua. Jakarta: Kencana Prenada Media Group.

Winner B (2012). Effectiveness of LongActing Reversible Contraception. The New England Journal of Medicine. 